\title{
Fritz Redlich: Scholar and Friend
}

\section{Kennéth E. Carpenter and Alfred D. Chandler, JR.}

Fritz Redlich, who died on October 21, 1978 in a nursing home in. Newton Center, Mass., should have been the emeritus holder of a professorship in a major German university, and in the normal course of things he should have died surrounded by family. Instead, he never held a tenured position in a university and lived out his final years in a one-room apartment in a rather shabby building near Harvard Square. If the life of Fritz Redlich was bereft of much personal happiness or formal success, it was a life of great accomplishment. It truly was, as he wrote in the introduction to Der.Unternehmer (1964), "ein Leben für die Forschung" (a life for research).

The combination that characterized the life of Fritz Redlich resulted from the events of world history and the nobility of the man. Born in 1892 in Berlin, the stability in which he grew up was shattered by the outbreak of the First World War. The Sunday evening after he had stood for his Ph.D. exam in economics brought news of the assassination of Franz Ferdinand. Less out of enthusiasm than a sense of duty, Redlich enlisted in the German army, and the new Ph.D. served as a junior officer on various fronts. Following the war, instead of returning to the academic world, he made the big mistake of his life, one which he bitterly regretted-he went to work in his father's chemical business. Not until 1930, after a sixteen-year absence from academia, did he resume his plan for a Habilitation. Fritz Redlich chose advertising as his topic. While at work on the Habilitationsschrift, he heard about a prize that had been offered by a Berlin banker for the best study of the history of German entrepreneurship. Since no work had been deemed worthy of the prize, Redlich decided to investigate the role of the entrepreneur in the historical portion of his study on advertising. From this came a resolve to pursue broad studies on the history of entrepreneurship.

In 1935 the Habilitationsschrift on advertising was published; but by then it was clear that no possibility existed for a professorship in a university system under Nazi control. A year later, on April 1, Fritz Redlich arrived in New York. He brought with him \$54, little knowledge of English, three chapters of his study on the history of German entrepreneurship, and most importantly, a close relationship, both personally and intellectually, with the great German scholars of the early twentieth century-Ignaz Jastrow, Otto Hintze, Werner Sombart, Max Weber, Ernst Troeltsch, and Wilhelm Dilthey. Two weeks later he visited Cambridge, where F. W. Taussig and Joseph Schumpeter encouraged him to turn to the study of American entrepreneurship.

There followed various teaching positions in different parts of the country, intermixed with periods of research, for which there was some modest support by F. W. Taussig, the New School for Social Research, and the Social Science Research Council. The first major result was volume 1 of his History of American Business Leaders.'

In the summer of 1942, Fritz Redlich resigned his position in the Economics Department at Mercer University, where he had been teaching since 1937, and took the gamble of moving to Cambridge. By then he had become a U.S. citizen, and he hoped to obtain a government post while at the same time having access to the Harvard libraries. In January

Journal of Economic History, Vol. XXXIX, No. 4 (Dec. 1979). (C) The Economic History Association. All rights reserved. ISSN 0022-0507.

The authors are Curator, The Kress Library of Business and Economics, and Isidor Straus Professor of Business History, Harvard Graduate. School of Business Administration.

' History of American Business Leaders: A Series of Studies, Vol. 1: Theory, Iron and Steel, Iron Ore Mining (Ann Arbor, 1940). 
1943, he was appointed economic analyst with the Federal Public Housing Authority, a position that mainly involved setting rents on government housing according to a system that he devised. From June 1948 to April 1950 he was director of research and statistics for the $\$ 200$ million public housing program of the Massachusetts State Housing Board. Throughout this period he frequently wrote from 5 to 7 in the morning and also pursued his research during other periods of free time. This work resulted in publication in 1947 of The Molding of American Banking, Men and Ideas, 1781-1840. The second part of this study was published in 1951, the beginning of the period that can only be called his halcyon days. ${ }^{2}$

In 1952 Arthur H. Cole obtained for Fritz Redlich an appointment as Senior Associate in the Research Center in Entrepreneurial History at Harvard. At the Center Fritz Redlich was clearly the major intellectual force. His was its most creative mind. This appointment meant that for the first time he could devote himself full time to his research and to discussion with able colleagues, both of his own generation and younger. For Redlich, these were golden years. A Swedish relative has written of him as being at that time" "relaxed and childishly happy, apparently in harmony with himself and his surroundings." For the junior members of the Center and those others who participated in its activities, the result was an influence that enriched all their subsequent work.

One of the authors of this memorial (Chandler) well remembers his first extended encounter with Fritz Redlich:

It was in the stacks at Baker Library where I was trying to find information on the shadowy figure, James F. D. Lanier, a major but little known investment banker of the 1850's with whom Henry Poor, the subject of my dissertation, was closely associated. Fritz immediately produced a mass of information culled from the most obscure sources and even pointed me to Lanier's autobiography which, because of an odd title, had been miscatalogued. As the dissertation moved on, Fritz continued to share his knowledge and to discuss the implications of my limited, though to me exciting, findings. Always he pushed me to address the larger questions of the role of business and businessmen in the world in which Poor lived and wrote about.

These discussions in turn led to even more lengthy ones on the role of the entrepreneur in enterprises such as the railroads and the large producing and distributing firms that were operated through extended managerial hierarchies. Our question was, what relevance did existing entrepreneurial theory, which assumed that decisions were made by individuals, have to businesses where decisions were made by teams or groups of managers?

These discussions, which lasted over several years, resulted in a joint article in which we tried to define the functions of the managers, at different levels of the organization. In so doing, Fritz, always a bear for precise definitions, invented a word for a new level of management where managers coordinated the activities of a number of operating units. "This then became the task of a new, middle level of business administration. For want of a better word, we will characterize it as the 'locum-tenential', level, because certain officers, other than the top team, and in lieu of it, undertake to administer on their own responsibility particular lines of products, a situation which implies supervision and coordination of the functional operators concerned." 3 .

The name did not last. It was much easier to say middle manager. But the distinction

\footnotetext{
${ }^{2}$ The Molding of American Banking; Men and Ideas. Pt. 1, 1781-1840 (New York, 1947), Pt. 2, 1840-1910 (New York, 1951). Both parts were reprinted in one volume in 1968 by the Johnson Reprint Corporation with an introduction (vol. 1 ', pp. $v-x x x)$ "to bring the original publication up to date by presenting and evaluating the banking literature published since the two volumes first came out."

${ }^{3}$ Alfred D. Chandler, Jr. and Fritz Redlich, "Recent Developments in American Business Administration and Their Conceptualization," Business History Review, 35 (Spring 1961), 21.
} 
remained. Where middle managers coordinated, the top team planned long-term policies and allocated resources to carry them out. This distinction between the function and the organization of the middle and top management has become standard doctrine in the teaching of and the practice of policy making in large business enterprises here and abroad.

Fritz always insisted that the writing of history must be more than descriptive if it was to lead to an understanding of the past and so of the present. This emphasis on analysis was one of Fritz's major contributions to the writing of history in this country. He probably did not realize how influential he was in helping to make analytical history take hold. In 1965 John Higham published History, a review of the ways Americans had and were writing about their past. For Higham, the two most significant post-war developments in the trade were the new psychological history and the new institutional history. As to the latter he wrote: .

Deriving partly from studies in entrepreneurial and business history and partly from contemporary American sociology, this kind of history is less concerned with motives and more with structure and process. It shows men managing and being managed through rational systems of control and communication. Perhaps we may call this the new institutionalism; for it is bringing back to life a morphological study of organizations, now freed from the formalistic evolutionary emphasis of nineteenth century scholarship. Although the institutionalists thus far have not gone much beyond the monographic level, the breadth and importance of their contribution seems sure to grow. ${ }^{4}$

One of the prime movers in the new institutional history that combined entrepreneurial, business history, and sociology surely was Fritz Redlich.

With the demise of the Research Center for Entrepreneurial History opportunities to exert this kind of influence became less frequent, and life for Fritz Redlich settled into a much less satisfying routine. The pattern was usually a morning or two a week in Baker Library at the Harvard Business School where Redlich helped select modern German books. At the same time, he would stop by Kress and gloat over new acquisitions there. Especially delighted by German books, he loved to see all new acquisitions, even if in languages he did not know. He took great pleasure in the growing international coverage of the collection, a course he strongly urged. Occasionally, a new acquisition would particularly interest him, and then he would be in Kress more frequently to do research and writing. Usually, though, he would be in Baker once or twice a week, with other mornings in Widener, followed by lunch, a nap, reading or writing, then a walk, dinner, and more reading or writing. On weekends, there might be a long visit to the Fogg Art Museum or to the Museum of Fine Arts.

In the last decade of his life, Fritz Redlich wrote less, perhaps only two or three papers a year, both because he did not feel he had the strength for a major project and because he feared producing work of less high quality. Most of his time was spent in.omnivorous reading of tremendous variety. In any one month he might read autobiographies of leading European communists, a play of Shakespeare, something by Gide, and part of the Bible. He went on reading binges on particular subjects, one of the last being the growing literature on terrorism. This latter topic shows how he triumphed over the isolation that pained him. Instead of withdrawing, he maintained a keen interest in the world around him and in the people of that world.

His greatest joy was in meetings, such as the Friends of Business and Economic History, visits from younger scholars, or visits with friends. Although he lived modestly in the extreme, his manuscripts being typed not simply on the backs of letters but often on envelopes pasted together, he never begrudged the expense of entertaining. He also loved to be

\footnotetext{
${ }^{4}$ John Higham, with Leonard Krieger and Felix Gilbert, History: Humanistic Scholarship in America (Englewood Cliffs, N.J., 1965), p. 231.
} 
entertained, particularly when he could sit in a garden on a sunny day and when there were children around. This elderly bachelor had an immense affection for children and younger people. He was especially drawn to young people going through crises. In his stay in Stillman Infirmary early in 1978, he spent long hours talking with a student in for psychiatric observation. One day just before she left, she rushed up to him and gave him a bouquet of flowers.

In such a relationship, as in others, Fritz Redlich did not see people in stereotypical ways. A teenager rebelling never elicited from him lamentations about the youth today. He saw people as individuals and often showed remarkable insight into their motives. This made him an exceedingly wise counselor, and he enjoyed that role. If his advice was sometimes as unsolicited as it was needed, he felt that was an old man's privilege--and even duty.

This quality of honesty made him an immensely valuable critic of others' writing. If one were willing to pay the price of submitting to an unflinching, thoroughgoing critique, the reward was great. Fritz Redlich would devote hours to someone else's paper without thought of his own time, and a number of readers of this JOURNAL would call him their most valued mentor. His criticism was so valuable, not just because he bore in on details, but also because he stimulated one to a broader vision.

Although his own experience had taught him that it was easier to obtain support for a "small, analytical project" than for a "large, synthetical" one, he always urged the latter. To be sure, he believed in a firm grounding in a discipline, but he felt that instead of going deeper and deeper into ever more minute topics, one should move from the central core out to the boundaries. By this he did not mean work that was marginally useful. On the contrary, the boundaries offered exciting possibilities for advancing understanding. This was one of the ideas behind his The German Military Enterpriser and His Work Force, ${ }^{5}$ a two-volume study little known in this country but in Germany considered his major work. He also believed strongly in comparative studies.

On looking closely at the career of Fritz Redlich, one is left with the feeling that his major contribution did not perhaps lie with his writings, as substantive in number and quality as they are. To be sure, few people write a work of synthesis that lasts for a chronological generation, and Richard Sylla could comment, twenty-five years after publication of the banking history, that it remained "the best single source for anyone interested in the whole of nineteenth century American banking."' Few also produce over 150 books and articles and have published two volumes of collected articles. One of those appeared in German at the instance of Edgar Salin, Der Unternehmer'; the other, Steeped in Two Cultures, came out in $1971 .{ }^{8}$ Yet, Fritz Redlich himself was dissatisfied with his accomplishments. One reason is that the younger generation turned to quantification, exactly the opposite of his emphasis on the personal element, and he felt that his work for the most part was not built upon. He also felt that inherently the theme of the entrepreneur in history was too narrow and not up to his capacities.

It was perhaps in conversation that his abilities were most clearly evident. There, the extraordinary breadth and originality of his mind was always apparent, and it was perhaps in the personal influence he exerted that his greatest contribution' lies. This was not only intellectual. Fritz Redlich was one of those who belonged to what Ortega y Gasset has called the nobility—nobility being "synonymous with a life of effort, ever set on excelling

\footnotetext{
${ }^{5}$ The German Military Enterpriser and His Work Force; A Study in European Economic and Social History (Wiesbaden, 1964-65; Vierteljahrschrift für Sozial- und Wirtschaftsgeschichte, nos. 47-48).

'Richard Sylla, "American Banking and Growth in the Nineteenth Century: A Partial View of the Terrain," Explorations in Entrepreneurial History, 9 (Winter 1971-72), 201-02.

${ }^{7}$ Der Unternehmer; Wirtschafts- und Sozialgeschichtliche Studien, mit einem Nachwort von Edgar Salin (Göttingen, 1964). This contains a list of Redlich's writings up through 1963.

${ }^{8}$ Steeped in Two Cultures: A Selection of Essays (New York and Evanston, 1971).
} 
oneself, in passing beyond what one is to what one sets up as a duty and an obligation." On the occasion of his eightieth birthday, at a party of well-wishers, Fritz Redlich gave a speech that, typically, was not about the past but about "Work Left Undone." It concluded with the words, "I shall have to leave pretty soon, and I hope I shall live in your memory: He was a man, take him for all in all." Fritz Redlich was more than a man "for all in all." As one of his younger colleagues has said, "He was, you know, a great man." 